\title{
The Strategy of Innovative Development of Economy of Ukraine till 2030
}

\section{Olena Kolishchuk ${ }^{1}$}

${ }^{1}$ The Bohdan Khmelnytsky National University of Cherkasy

81 Shevchenko Boulevard, Cherkasy, 18031, Ukraine

DOI: $10.22178 /$ pos.54-2

JEL Classification: 031

Received 28.12.2019

Accepted 28.01.2020

Published online 31.01.2020

Corresponding Author: olenakolischuk@gmail.com

(c) 2020 The Author. This article is licensed under a Creative Commons Attribution 4.0 License @ (1)
Abstract. The Strategy of the development of the innovative activity sphere for the period up to 2030 approved by the Government of Ukraine has been analyzed in the article. It was determined that the innovative activity sphere has several disadvantages. The following issues have not been considered: application of tax privileges for the activation of innovative activity of domestic enterprises; implementation of the list of specific innovative projects, which are fully or partially financed from the state budget; direct connection of the state with business and society; mechanism of interaction between universities and domestic enterprises; people responsible for the implementation of the Country Innovation Strategy at the state and local levels have not been assigned; the priority of public procurement of high-tech products from domestic manufacturers has not been established; mechanisms of annual monitoring and control of the stages of strategy implementation have not been defined.

The ways of overcoming these issues have been provided in the article. An algorithm of the implementation of the Innovative Development Strategy of Ukraine until 2030 has been developed and suggested, which will make the state policy in the sphere of innovation activity more systematic and advanced. The suggested algorithm of strategy implementation consists of five main stages: preparatory, computational, organizational, practical implementation and result from analysis. At each of these stages, the functions and responsibilities of each participant in the innovation process are defined: the state, research institutions, local governments, and business structures. The deadlines for the implementation of necessary transformations and practical mechanisms for their realization have been determined. The role of state bodies as the main organizational element of the Strategy development is highlighted. The algorithm of the realization of the Strategy of Innovative Development of the Ukrainian Economy suggested by the author will ensure the consistent and gradual implementation of the structural elements of the national innovation system, its effective transformation, and further development, since each step of the Strategy is a logical stage of implementing a comprehensive program to ensure the development of innovative relations in the state's economy.

Keywords: strategy of innovative development of economy; innovation activity; innovation process; Ukraine.

\section{INTRODUCTION}

In the context of increasing globalization processes, one of the most effective tools of successful management of the country's economy is a well-grounded strategy of innovative development. More and more countries are recognizing innovative development as a key to the sustainable economic advancement of current and future economies. In the context of deepening relations with the EU, Ukraine's economy must be particularly competitive and, above all, through the introduction of new technologies and innovative industries. However, the analysis of the innovative state of the Ukrainian economy indicates that the innovation component is insufficient. To be precise, the approved Strategy of the development of the sphere of innovative activity for the period up to 2030 has several shortcomings and is not systematic. A well-developed strategy of innovative economic development depends on whether Ukraine can realize its industrial potential and make efficient use of the available labor and financial resources in the nearest future. Considering this aspect, the issue of the development of the strategy of the innovative state's economic advancement is relevant and important. 
The scientific literature of different countries explores the issues of working out a strategy of innovative economic development. Domestic and foreign scientists analyze the current condition of innovative strategies in detail. These include Y. Zhang [12], J. Jung [4], Y. Izmaylov, D. Znotina and H. Puriy [3], A. Zabolotko [11], M. Lazyrin [6], A. Shumilin [8], V. Belsky and L. Trigubovich [1], A. Sandybayev and R. Houjeir [2], A. Lewandowska [7] and others.

The aim of this study is the analytical study of the development of the innovative activity sphere for the period up to 2030 approved by the Government of Ukraine as well as objective assessment of its conceptual statements to comply with the requirements of the current state of development of the national innovation system along with provision of suggestions for the improvement of the organizational structure of the strategy and definition of the required stages of its consistent implementation.

\section{MATERIALS AND METHODS}

To achieve this goal, the following general scientific methods were used: comparative, functional, systematic, analysis and generalization, which made it possible to thoroughly consider the current strategy of innovative development of the Ukrainian economy and to suggest the author's algorithm of the strategy development.

\section{RESULTS AND DISCUSSION}

For the successful innovative development of the country's economy, an appropriate strategy must be developed and approved. The Decree of the Cabinet of Ministers of Ukraine dated July 10, 2019 , approved the Strategy for the development of the sphere of innovative activity for the period up to 2030 (hereinafter - the Strategy 2030), aimed at solving the issues of innovation activity development [10]. The results of the synergistic analysis of the content of the 2030 Strategy revealed that it had several shortcomings. The following issues have not been considered:

- application of tax privileges for the activation of innovative activity of domestic enterprises;

- implementation of the list of specific innovative projects, which are fully or partially financed from the state budget;

- direct connection of the state with business and society;
- mechanism of interaction between universities and domestic enterprises;

- people responsible for the implementation of the Country Innovation Strategy at the state and local levels have not been assigned;

- the priority of public procurement of high-tech products from domestic manufacturers has not been established;

- mechanisms for annual monitoring and control of the stages of strategy implementation are not defined.

As to the first drawback, the use of tax incentives to stimulate innovation has already justified itself in most industrialized countries, so we consider it appropriate to introduce tax incentives for companies in industries that have been identified as priority or strategic.

Speaking about the second shortcoming, we believe that the annex should be added upon the approval of Strategy 2030 so that it should be completed as a result of project implementation. For example, the project of retrofitting all multistory buildings from district to autonomous heating to save consumers' budget, which is economically viable and will reduce heating expenses by 3-4 times, according to our calculations.

The third shortcoming of the Strategy could be eliminated through the Internet referendum, where each citizen would be offered to provide suggestions for the improvement and advancement of the innovative environment of Ukraine.

The fourth shortcoming could be solved in the following way: to open the reception of applications from enterprises in each university, to declare the skills and knowledge required for modern manufacture in a certain specialty. Considering such preferences, a university adjusts the educational program, while the applying companies hire students to shape their future professional skills during their summer internship. The positive effect of such cooperation for students will be manifested in the ability to work on modern equipment instead of technically outdated models. Under such conditions, companies will be able to hire both theoretically and practically prepared students.

As to the fifth shortcoming, it can be eliminated by appointing the officials from the Ministry of Economic Development, Trade and Agriculture, Ministry of Education and Science and Ministry of Digital Transformation as responsible people 
for the implementation of the strategy of innovative development of Ukraine's economy. Their functional responsibilities will include organization and control of the implementation of the innovative activity.

The sixth drawback can be on the legal level, stating that domestic manufacturers should get the priority when carrying out state purchases of high-tech products at the expense of budgetary funds. For example, when purchasing motor vehicles, the order should be made from domestic enterprises, which will provide Ukrainian manufacturers with orders and ensure employment opportunities to thousands of citizens.

The seventh shortcoming should be corrected by the introduction of mandatory annual statistical reporting for enterprises, involved in innovative activity. As an encouraging incentive for them, it would be reasonable to recognize the possibility of applying for tax benefits, if the volume of revenue from the sale of innovative products is not less than $70 \%$ in the total volume of sales, according to the results of the previous reporting period (the previous calendar year).

Having analyzed the content of Strategy 2030 and taking into account the above-listed comments, we provide our suggestion of the algorithm of implementation of the main statements of Strategy 2030 (Table 1).

The purpose of our suggested strategy implementation algorithm (Table 1) is the need to make Ukraine's innovation policy more systematic, innovation-oriented and efficient, which should ensure the required coordinated political, economic, social and technological changes in the industrial sector of the economy and Ukrainian society as a whole. The step-by-step introduction of elements of the national innovation system, in our opinion, will provide an opportunity to ensure its effective transformation and further development, since each subsequent stage of the strategy is a logical and consistent step of implementing a comprehensive program of actions for building innovatively-developed relations between the state, local self-governing bodies, and local scientific bodies, institutions, and businesses. At each of these stages, the state should play a leading role in creating and maintaining the functioning of the innovation ecosystem: predictive analytical studies, planning and defining the prospects for innovative development of the national economy, creating the necessary legislative framework in the field of innovation, supporting the development of economic entities that carry out innovative activity, infrastructure and research activities, formation of favorable innovative business - climate of the country. To ensure these measures, the state authorities of Ukraine should use a flexible set of economic, political and interdisciplinary methods of management in the sphere of innovative activity and related industries, ensuring its functioning, progressive orientation, and creative development.

Thus, on the first - preparatory stage of the strategy, the Cabinet of Ministers of Ukraine should oblige scientific and research institutions of the Ministry of Education and Science to conduct an assessment of the innovative state of the domestic economy as soon as possible, identify weaknesses and strengths of it, according to the State Statistics Service of Ukraine to calculate available industrial, financial and country's human resources potential to identify sectoral benefits. Also, it is necessary to take into account the research of reputable international expert companies that monitor the state of innovation activity of countries, including Ukraine, and provide an independent objective assessment of positive and negative factors of its development. This will give an opportunity to thoroughly analyze legal, organizational, financial and technological advantages and disadvantages of the country in the implementation of innovative projects, to find out mechanisms for fulfilling the objectives of national innovation development. That is, the main role of the State in the first stage of the Strategy lies in the planned - grounded formation of innovation policy, taking into account the real possibility of realization of all potential gains of the country: industrial, financial, scientific, which will ensure efficient use of innovations in a wide range of industries of the national economy.

On the second - computational- stage of the Ministry of Education and Science and the Ministry of Economic Development, the innovative potential of the national economy is evaluated, priority ways of its development are determined, appropriate programs and plans for its consistent implementation over the next 10 years are defined and specific actions for the implementation of such programs are outlined. 
Table 1 - An algorithm of implementation of the strategy of innovative development of the economy of Ukraine until 2030

\begin{tabular}{|c|c|c|c|c|c|}
\hline Stage & Goal & $\begin{array}{c}\text { Methods of } \\
\text { implementation }\end{array}$ & Deadline & Planned result & $\begin{array}{l}\text { Responsible } \\
\text { executors }\end{array}$ \\
\hline I. Preparatory & $\begin{array}{l}\text { Assess the state of } \\
\text { innovative } \\
\text { development of the } \\
\text { economy }\end{array}$ & $\begin{array}{l}\text { Assessment of the } \\
\text { innovative state of } \\
\text { the economy }\end{array}$ & 3 months & $\begin{array}{l}\text { Identification of } \\
\text { weaknesses and } \\
\text { strengths of } \\
\text { innovative } \\
\text { development }\end{array}$ & $\begin{array}{l}\text { Ministry of } \\
\text { Education and } \\
\text { Science, the } \\
\text { State Statistics } \\
\text { Service, } \\
\text { Ministry of } \\
\text { Economic } \\
\text { Development }\end{array}$ \\
\hline II. Computational & \begin{tabular}{|l|} 
Calculation of costs \\
and future \\
revenues from \\
strategy \\
implementation
\end{tabular} & $\begin{array}{l}\text { Assessment of the } \\
\text { potential of } \\
\text { innovative economic } \\
\text { development. } \\
\text { Definition of } \\
\text { concrete actions and } \\
\text { calculation of } \\
\text { economic effect } \\
\text { from their } \\
\text { implementation. }\end{array}$ & 3 months & $\begin{array}{l}\text { Selection of } \\
\text { priority directions } \\
\text { of innovative } \\
\text { development of } \\
\text { national economy. } \\
\text { Development of } \\
\text { programs and } \\
\text { plans for 2-4-6-8- } \\
10 \text { years. }\end{array}$ & \begin{tabular}{|l} 
Ministry of \\
Education and \\
Science, \\
Ministry of \\
Economic \\
Development, \\
Council for \\
Innovation \\
Development \\
under the \\
Cabinet of \\
Ministers \\
\end{tabular} \\
\hline III. Organizational & \begin{tabular}{|l|} 
Provide the \\
legislative basis for \\
the activation of \\
innovative projects. \\
Formation of \\
programs for \\
innovative \\
development of \\
industries and \\
regions with the \\
assignment of \\
responsible \\
officials. Definition \\
of practical ways of \\
their realization.
\end{tabular} & $\begin{array}{l}\text { Application of a set } \\
\text { of organizational } \\
\text { and practical } \\
\text { national measures. } \\
\text { Development of } \\
\text { mechanisms for } \\
\text { implementation of } \\
\text { innovative } \\
\text { programs. Revision } \\
\text { of existing } \\
\text { regulatory acts, } \\
\text { bringing them into } \\
\text { line with current } \\
\text { conditions of } \\
\text { economic } \\
\text { development of the } \\
\text { country. }\end{array}$ & Indefinitely & $\begin{array}{l}\text { Construction } \\
\text { machinery for } \\
\text { realizing } \\
\text { innovative } \\
\text { programs. } \\
\text { Confirmation of } \\
\text { laws, the decree of } \\
\text { those statutory } \\
\text { legal acts with the } \\
\text { aim of innovative } \\
\text { development of the } \\
\text { economy of } \\
\text { Ukraine, with } \\
\text { preferences for the } \\
\text { activation of } \\
\text { innovative } \\
\text { activities. }\end{array}$ & $\begin{array}{l}\text { Verkhovna } \\
\text { Rada, Ministry } \\
\text { of Education } \\
\text { and Science, } \\
\text { Ministry of } \\
\text { Economic } \\
\text { Development, } \\
\text { local executive } \\
\text { authorities, } \\
\text { Council for } \\
\text { Innovation } \\
\text { Development } \\
\text { under the } \\
\text { Cabinet of } \\
\text { Ministers }\end{array}$ \\
\hline $\begin{array}{l}\text { IV. Practical } \\
\text { Implementation }\end{array}$ & $\begin{array}{l}\text { Active development } \\
\text { of innovative } \\
\text { activities of } \\
\text { enterprises }\end{array}$ & $\begin{array}{l}\text { Implementation of } \\
\text { innovative } \\
\text { programs, the } \\
\text { relationship: state - } \\
\text { business - science. } \\
\text { Open dialogue. } \\
\text { Program correction. }\end{array}$ & Indefinitely & $\begin{array}{l}\text { Evaluation of the } \\
\text { results of strategy } \\
\text { implementation } \\
\text { each year. } \\
\text { Adjustment of } \\
\text { organizational and } \\
\text { practical status in } \\
\text { case of failure of } \\
\text { the annual planned } \\
\text { indicators. }\end{array}$ & $\begin{array}{l}\text { Verkhovna } \\
\text { Rada, Ministry } \\
\text { of Education } \\
\text { and Science, } \\
\text { Ministry of } \\
\text { Economic } \\
\text { Development, } \\
\text { local executive } \\
\text { authorities, } \\
\text { Council for } \\
\text { Innovation } \\
\text { Development } \\
\text { under the } \\
\text { Cabinet of } \\
\text { Ministers }\end{array}$ \\
\hline
\end{tabular}




\begin{tabular}{|l|l|l|l|l|l|}
\hline \multicolumn{1}{|c|}{ Stage } & \multicolumn{1}{|c|}{ Goal } & \multicolumn{1}{|c|}{$\begin{array}{c}\text { Methods of } \\
\text { implementation }\end{array}$} & \multicolumn{1}{c|}{ Deadline } & \multicolumn{1}{c|}{ Planned result } & \multicolumn{1}{c|}{$\begin{array}{c}\text { Responsible } \\
\text { executors }\end{array}$} \\
\hline $\begin{array}{l}\text { V. Analysis of } \\
\text { results }\end{array}$ & $\begin{array}{l}\text { Evaluate the results } \\
\text { and effectiveness of } \\
\text { the strategy }\end{array}$ & $\begin{array}{l}\text { Evaluation of the } \\
\text { results of strategy } \\
\text { implementation } \\
\text { each year. } \\
\text { Adjustment of } \\
\text { organizational and } \\
\text { practical status in } \\
\text { case of failure of the } \\
\text { annual planned } \\
\text { indicators. }\end{array}$ & Yearly & $\begin{array}{l}\text { Analysis of } \\
\text { research of } \\
\text { innovative } \\
\text { programs for 2-4- } \\
6-8-10 \text { years. } \\
\text { Adjustments due to } \\
\text { unfulfilled } \\
\text { planning factors. }\end{array}$ & $\begin{array}{l}\text { the State } \\
\text { Statistics } \\
\text { Service, Council } \\
\text { for Innovation } \\
\text { Development } \\
\text { under the } \\
\text { Cabinet of } \\
\text { Ministers, } \\
\text { Ministry of } \\
\text { Education and } \\
\text { Science, } \\
\text { Ministry of } \\
\text { Economic } \\
\text { Development, } \\
\text { local executive } \\
\text { authorities }\end{array}$ \\
\hline
\end{tabular}

Source: own design

In the years of market transformation, Ukraine has lost so many opportunities. Thus, in 2018, GDP was $63.4 \%$ by 1991 [9]. If we analyze the indicators of the State Statistics Service of Ukraine on the impact of innovation activity on the output of production by industrial enterprises of Ukraine, it should be noted that such activity had a negative tendency, since the share of innovative products in the total volume of sales, for example, in 2000 was $9.4 \%$, and in 2018 - only $0.8 \%$. It is the opinion of the authors of Strategy 2030 [10] that as of 2030, this figure should be increased to $10 \%$. However, from our point of view, even reaching this $10 \%$ level is not sufficient to support Ukraine's GDP growth to 1991 levels. According to our calculations, the share of innovative products in the total volume of sales should be at least $20 \%$, to ensure active innovative development of the economy. To reach this level, the above-mentioned shortcomings in the approved Strategy 2030 [10], as well as under the condition of a radical restructuring of the national innovation system, focus on improving the main indicators of the economic development of Ukraine, should be eliminated. According to the definition of specialists I. Kukurudza and A. Proshchalykina, this "... depends on the success of solving several problems: creation of a favorable institutional and legal environment for the development of innovative activity, formation of appropriate infrastructure, enhancement of motivation and activation of innovation activity of enterprises, improvement of the security system and the use of IP, development of a training sys- tem for innovation, enhancement of the coordinating role of the state in ensuring the interaction of NIS elements, promotion of the innovation regional development"[5].

On the third - organizational - stage of the strategy, it is necessary to apply national organizational and practical measures: to develop effective mechanisms of implementation of innovative programs based on the principles of partnership and mutual benefit. On this stage, state support (financial, preferential, etc.) provides the priorities and projects that have been formed within the technological platforms as decisive, and the entities in the early stages of innovation implementation. At the state level, systems of grant and non-state financing of innovative projects are being created. To ensure these measures, it is necessary to review the normative legal acts in the innovation sphere and to bring them into line with the current conditions of economic, political and social development of the country.

On the fourth stage - implementation of innovative programs is carried out, there is an active development of the innovative activity of enterprises, their number is increasing. Open dialogue: state - science - business provides interconnection between all links of the innovation process, which allows to make prompt adjustments of programs and make necessary changes to innovative projects.

On the fifth stage, the results of the implementation of the strategy and the effectiveness of its impact on the development of the national economy are evaluated. Also, every year, based on the 
results of the mid-term evaluation, organizational and practical measures are adjusted, if necessary, to comply with certain indicative indicators of innovative development.

\section{CONCLUSIONS}

The conducted analysis of the Strategy of development of the sphere of innovative activity for the period till 2030 shows that the current Strategy has several shortcomings, therefore in this article, the ways of their solution are suggested. The implementation of the algorithm offered by the author of the implementation of the Strategy of innovative development of the national economy will achieve its main goal: to carry out the necessary thorough legislative, economic, technological and social transformations and changes in the industrial sector of the national economy to organize the production of domestic competitive products and provide the population with quality products. The implementation of the strategy suggested by the author is necessary for the creation and development of an innovative economy of Ukraine.

\section{REFERENCES}

1. Belsky, V., \& Trigubovich, L. (2017). Problema aktivizacii innovacionnogo razvitija Respubliki Bularus' [The problem of activation of innovative development of the Republic of Belarus]. Economics and national economy management, 5, 116-126 (in Russian)

[Бельский, В., \& Тригубович, Л. (2017). Проблема активизации инновационного развития Республики Буларусь. Экономика и управление народным хозяйством, 5, 116-126].

2. Innovation as a Source of Competitive Advantage in Human Resource Management: Case of Travel Agencies in the UAE. (2018). International Journal of Research in Tourism and Hospitality, 4(2). doi: 10.20431/2455-0043.0402006

3. Izmaylov, Y., Znotina, D., \& Puriy, H. (2017). Strategic priorities of ukraine's investment and innovation development in modern international economic environment. Scientific Journal of Polonia University, 24(5), 39. doi: 10.23856/2405

4. Jung, J. (2016, December 15). China's Innovation-Driven Development Strategy and Prospects. Retrieved from https://thinkasia.org/bitstream/handle/11540/10758/KIEPopinions_no98.pdf?sequence=3

5. Kukurudza, I., \& Proshchalykina, A. (2011). Innovative activity: the state and role in the economic growth of countries with a transformational economy. Cherkasy: CNU.

6. Lazyrin, M. (2017). Prepjatstvija na puti innovacionnogo razvitija RF [Obstacles for the innovation development of Russia]. International Research Journal, 1(55), 30-32 (in Russian)

[Лазырин, М. (2017). Препятствия на пути инновационного развития РФ. Международный научно-исследовательский журнал, 1(55),30-32].

7. Lewandowska, A. (2012). Regional Innovation Strategy as a Management Instrument of Innovation Policy in the Region Poland. Retrieved from

https://www.researchgate.net/publication/273949395_Regional_Innovation_Strategy_as_a_ma nagement_instrument_of_innovation_policy_in_the_region_Poland

8. Shumilin, A. (2015). o koncepcii gosudarstvennoj programmy innovacionnogo razvitija Respubliki Belarus' na 2016-2020 gg. [About the Concept of the State Program of Innovative Development of the Republic of Belarus for 2016-2020]. News of Science and Technologies, 2(33), 6-15 (in Russian)

[Шумилин, А. (2015). О концепции государственной программы инновационного развития Республики Беларусь на 2016-2020 гг. Новости науки и технологий, 2(33), 615].

9. State Statistics Service of Ukraine. (2019). Economic statistics. National accounts. Retrieved December 1, 2019, from http://www.ukrstat.gov.ua/operativ/menu/menu_e/nac_r.htm 
10. Stratehiia rozvytku sfery innovatsiinoi diialnosti na period do 2030 roku [Strategy of development of the sphere of innovative activity for the period till 2030] (Ukraine), 10.07.2019, No 526-p. Retrieved December 1, 2019, from https://zakon.rada.gov.ua/laws/show/526-2019-\%D1\%80 (in Ukrainian)

[Стратегія розвитку сфери інноваційної діяльності на період до 2030 року (Україна), 10.07.2019, № 526-р. Актуально на 01.12.2019. URL:

https://zakon.rada.gov.ua/laws/show/526-2019-\%D1\%80].

11. Zabolotko, A. (2013). Stratehyia ynnovatsyonnoho razvytyia [Innovation Strategy]. Journal of Economic Regulation, 4(2), 84-92 (in Russian)

[Заболотько, А. (2013). Стратегия инновационного развития. Вопросы регулирования экономики, 4(2), 84-92].

12. Zhang, Y. (2019). Innovation-driven development strategy puts country into Top. China Daily. Retrieved February 25, 2019, from

http://www.chinadaily.com.cn/a/201902/25/WS5c7343e2a3106c65c34eb213.html 